\title{
Assessment of Delay Factors in Saudi Arabia Railway/Metro Construction Projects
}

\section{Raja Khan Mohammed Gopang ${ }^{1}$, Qadir Bux alias Imran², Sasitharan Nagapan ${ }^{1}$}

${ }^{1}$ Faculty of Civil and Environmental Engineering,

Universiti Tun Hussein Onn Malaysia (UTHM), 86400, Parit Raja, MALAYSIA

${ }^{2}$ Department of Civil and Environmental Engineering, College of Engineering and Architecture, University of Nizwa, P O Box 33, P C 616, Nizwa, OMAN

*Corresponding Author

DOI: https://doi.org/10.30880/ijscet.2020.11.02.028

Received 30 July 2020; Accepted 30 August 2020; Available online 02 September 2020

\begin{abstract}
Railway construction industry has devoted vast amount of resources into advancing the management and technology of railway construction, yet most project in this industry often failed to comply with the set deadlines and budget limits. This study was conducted to recognize the critical factors that are causing delays in the construction of Riyadh Metro project, Saudi Arabia. From a thorough literature review, thirty-six (36) factors causing delays were identified which were then distributed to qualified industry experts in a survey questionnaire. A total of 105 respondents were gathered during the data collection. The data was then evaluated statistically by utilizing different calculation tools that are frequency adjusted importance index for the delay factor ranking, and Spearman's correlation coefficient for the link between two different set of data. The result of this research identified the top five main delay factors to the railway construction projects which are "Client's decision-making process and changes in control procedures", "Design Errors (including ambiguities and discrepancies of details/specifications)", "Labor skills level", "Design changes by Client or Consultant" and lastly, "Issues regarding permissions/ approvals from other stakeholders". Finally, this study is hoped to help the railway construction industry in bettering itself by highlighting which issues should be focused on to counter the delays and reduce downtimes.
\end{abstract}

Keywords: Time overrun, delay factors, Riyadh Metro Rail

\section{Introduction}

Construction projects pose a challenge to the client, consultant and the contractor due to financial constraints and the timely delivery of projects. As delays hamper project progress and adds unnecessary burden to the budget and time constraints, it is hard for projects to achieve sustainable development, as construction organizations are implementing corporate strategic objectives in projects, it is imperative that project management to identify and recognize the factors that are causing the most delays as it will help for future sustainable development (Ghosh et al., 2014). Flyvbjerg (2015) estimated that spending on mega projects globally could be approximately $8 \%$ of the total global gross domestic product (GDP) that is between US\$6 trillion to US\$9 trillion annually. In developing countries, the infrastructure projects are the core plan of the authorities and they heavily invest in it. However, the delays from the construction project could significantly affect the nation's outcome and outlook. As this is the case there is a need to research on the delay causing factors of construction projects especially the Riyadh Metro project which is one of the key construction plans of the Saudi Arabia. The findings from this study will help the interested parties to manage the construction successfully by helping the managers of the project to see which factors would cost them more delays. 


\section{Literature Review}

Gunduz et.al 2015 defined delay as not achieving the desired project progress in the duration stated as per contract agreement. While, researchers define that it as the unforeseen uncertainty in the construction phase of projects (Hossen et al 2015), (Gardezi, et al 2014). While another researcher describes construction delays to be the challenges of project execution (Van et al 2016) and numerous researchers have recognized delays as "time overrun, which caused extension of time to complete construction projects" (Gardezi, et al 2014), (Marzouk and El-Rasas 2014), (Assaf and Al-Hejji 2006). Al-Kharashi and Skitmore (2009) described how project delays result in the loss of revenue and deliverables since the workers are idle but are required to remain on the project and therefore unable to work on other construction projects (Al-Kharashi and Skitmore, 2009). The delays to the construction of projects affect the industry across the globe and often viewed as the most challenging construction issue (Gardezi, et al 2014), (Van et al 2016), (Senouci et al 2016). Despite this, the construction industry is still able to maintain a higher share of expenditure in most developing countries' economy as it is vital for the nation infrastructure growth (Van et al 2016). As this is the case, time overrun may bring about late project completion, expanded cost, loss of efficiency, and lowered construction quality which shows the importance to investigate issue as it will hamper the growth of a nation (Gunduz and Yahya, 2018). Additionally, the advantage lost by the company would cost other opportunities or different tasks lost and missing out due to its project delay. In year 2018, Saudi Arabia's Ministry of Municipal and Rural Affairs (MOMRA), published a fact sheet of construction projects of the country which detailed out that approximately $75 \%$ of projects were delayed and exceeded the stated duration in the contract. While Al-ghafly, stated that on average, $39 \%$ additional time were required to complete the projects in the country (Al-ghafly 1999). Consequently, Faridi and El-Sayegh (2006) described that the Kingdom of Saudi Arabia reported that out of 2,379 construction projects, 952 of these projects have experienced delay which are approximately $40 \%$ of those projects (Faridi and El-Sayegh 2006). In the Saudi Arabia Eastern region, Assaf and Al-Hejji (2006) conducted a study on project delays and found that $70 \%$ of projects experienced delays and the approximate delays duration in time were recorded to be between 10-30\% of the estimated time (Assaf and Al-Hejji, 2006). Hence, this shows that the Saudi Arabia construction industry continues to suffer from poor performance from projects unable to meet the deadlines and the set budget (Alsuliman et al 2012).

\subsection{Causes of Construction Delays}

A comprehensive literature review was carried out for this research and managed to list a number of delay factors that are contributing to project delays which are shown as table 1.

Table 1 - Construction delay factors

\begin{tabular}{|c|c|c|}
\hline No & Delay Factors & References \\
\hline 1 & Inaccurate supplemental design information & $\begin{array}{l}\text { (Alwi and Hampson, 2003) (Enshassi et al 2009) (Ogunlana } \\
\text { 1996) }\end{array}$ \\
\hline 2 & $\begin{array}{l}\text { Construction site conditions (location, Harvest } \\
\text { time, Hot and cold, etc.) }\end{array}$ & $\begin{array}{l}\text { (Alwi and Hampson, 2003) (Enshassi et al 2009) (Ogunlana } \\
\text { 1996) (Kaming et al 1997), (Elinwa and Joshua 2001) } \\
\text { (Ahmed et al 2002), (Chan and Kumaraswamy 2002), (Odeh } \\
\text { and Battaineh 2002), (Al-Najjar, 2008), (Orangi et al 2011), } \\
\text { (Sweis et al 2008) (Imran Latif 2019), (Alias Imran Latif et al } \\
\text { 2020). }\end{array}$ \\
\hline 3 & $\begin{array}{l}\text { Clients' decision-making process and change } \\
\text { control procedures }\end{array}$ & $\begin{array}{l}\text { (Alwi and Hampson, 2003) (Enshassi et al 2009) (Ogunlana } \\
\text { 1996), (Ahmed et al 2002), (Odeh et al 2002), (Al-Najjar } \\
\text { 2008), (Sweis et al 2008) (Mahamid, 2017), (Chan et al 2013) } \\
\text { (Zaneldin 2006) (Imran Latif 2019), (Alias Imran Latif et al } \\
\text { 2020). }\end{array}$ \\
\hline 4 & $\begin{array}{l}\text { Insufficient communication between the } \\
\text { owner(s) and the consultant(s) }\end{array}$ & $\begin{array}{l}\text { (Al-Najjar 2008), (Orangi et al 2011), (Sweis et al 2008), } \\
\text { (Mahamid 2017), (Zaneldin 2006), (Le-Hoai et al 2008), } \\
\text { (Imran Latif 2019), (Alias Imran Latif et al 2020). }\end{array}$ \\
\hline 5 & Design team experience & $\begin{array}{l}\text { (Alwi and Hampson, 2003), (Enshassi et al 2009), (Al-Najjar } \\
\text { 2008), (Sweis et al 2008), (Ogunlana et al1996) }\end{array}$ \\
\hline 6 & $\begin{array}{l}\text { Design Errors and delays (including ambiguities } \\
\text { and discrepancies of details/ specifications) }\end{array}$ & $\begin{array}{l}\text { (Alwi and Hampson, 2003), (Enshassi et al 2009), (Ogunlana } \\
\text { 1996), (Chan and Kumaraswamy 2002) (Orangi et al 2011), } \\
\text { (Le-Hoai et al 2008), (Abdul-Rahman et al 2006) }\end{array}$ \\
\hline 7 & $\begin{array}{l}\text { Issues regarding permissions/ approvals from } \\
\text { other stakeholders }\end{array}$ & $\begin{array}{l}\text { (Al-Najjar 2008), (Orangi et al 2011), (Imran Latif 2019), } \\
\text { (Alias Imran Latif et al 2020). }\end{array}$ \\
\hline 8 & $\begin{array}{l}\text { External work due to public agencies, } \\
\text { Government regulation }\end{array}$ & (Enshassi et al 2009), (Al-Najjar 2008), (Sweis et al 2008), \\
\hline 9 & Delivery of material & $\begin{array}{l}\text { (Alwi and Hampson, 2003), (Enshassi et al 2009), (Ogunlana } \\
\text { 1996), (Kaming et al 1997), (Elinwa and Joshua 2001), }\end{array}$ \\
\hline
\end{tabular}




\begin{tabular}{|c|c|c|}
\hline No & Delay Factors & References \\
\hline & & $\begin{array}{l}\text { (Ahmed et al 2002), (Ogunlana et al 1996), (Kazaz et al 2012) } \\
\text { (Imran Latif 2019), (Alias Imran Latif et al 2020). }\end{array}$ \\
\hline 10 & Poor procurement programming of materials & $\begin{array}{l}\text { (Ogunlana et al 1996), (Abdul-Rahman et al 2006), (Imran } \\
\text { Latif 2019), (Alias Imran Latif et al 2020). }\end{array}$ \\
\hline 11 & Storage of materials & $\begin{array}{l}\text { (Alwi and Hampson, 2003), (Le-Hoai et al 2008), (Le-Hoai et } \\
\text { al 2008), (Kazaz et al 2012) (Imran Latif 2019), (Alias Imran } \\
\text { Latif et al 2020). }\end{array}$ \\
\hline 12 & Low quality of materials & $\begin{array}{l}\text { (Alwi and Hampson, 2003) (Enshassi et al 2009) (Imran Latif } \\
\text { 2019), (Alias Imran Latif et al 2020). }\end{array}$ \\
\hline 13 & Material supply monopoly & (Al-Najjar 2008), (Orangi et al 2011) (Sweis et al 2008) \\
\hline 14 & Lack of technical skill & $\begin{array}{l}\text { (Odeh et al 2002) (Al-Najjar 2008), (Sweis et al 2008), } \\
\text { (Ogunlana et al1996), (Zaneldin 2006) (Kazaz et al 2012) } \\
\text { (Imran Latif 2019), (Alias Imran Latif et al 2020). }\end{array}$ \\
\hline 15 & Labor skills level & $\begin{array}{l}\text { (Alwi and Hampson, 2003), (Enshassi et al 2009), (Ogunlana } \\
\text { 1996), (Kaming et al 1997), (Ahmed et al 2002), (Chan and } \\
\text { Kumaraswamy 2002) (Odeh et al 2002) (Al-Najjar 2008), } \\
\text { (Sweis et al 2008), (Mahamid 2017), (Ogunlana et al1996), } \\
\text { (Zaneldin 2006) (Kazaz et al 2012) (Imran Latif 2019), (Alias } \\
\text { Imran Latif et al 2020). }\end{array}$ \\
\hline 16 & Availability of labor & $\begin{array}{l}\text { (Alwi and Hampson, 2003), (Enshassi et al 2009), (Ogunlana } \\
\text { 1996), (Kaming et al 1997), (Ahmed et al 2002), (Chan and } \\
\text { Kumaraswamy 2002) (Odeh et al 2002) (Al-Najjar 2008), } \\
\text { (Sweis et al 2008), (Mahamid 2017), (Zaneldin 2006) (Kazaz } \\
\text { et al 2012) (Imran Latif 2019), (Alias Imran Latif et al 2020). }\end{array}$ \\
\hline 17 & Productivity of labor & $\begin{array}{l}\text { (Alwi and Hampson, 2003), (Enshassi et al 2009), (Ogunlana } \\
\text { 1996), (Kaming et al 1997), (Ahmed et al 2002), (Chan and } \\
\text { Kumaraswamy 2002) (Odeh et al 2002) (Al-Najjar 2008), } \\
\text { (Sweis et al 2008), (Mahamid 2017), (Zaneldin 2006) (Kazaz } \\
\text { et al 2012) (Imran Latif 2019), (Alias Imran Latif et al 2020). }\end{array}$ \\
\hline 18 & Equipment quality & $\begin{array}{l}\text { (Alwi and Hampson, 2003), (Enshassi et al 2009), (Elinwa } \\
\text { and Joshua 2001), (Ahmed et al 2002), Odeh et al 2002) } \\
\text { (Sweis et al 2008), (Mahamid 2017), (Ogunlana et al1996), } \\
\text { (Abdul-Rahman et al 2006), (Imran Latif 2019), (Alias Imran } \\
\text { Latif et al 2020). }\end{array}$ \\
\hline 19 & Equipment breakdown & $\begin{array}{l}\text { (Alwi and Hampson, 2003), (Enshassi et al 2009), (Ogunlana } \\
\text { 1996), (Kaming et al 1997), (Elinwa and Joshua 2001), Odeh } \\
\text { et al 2002) (Sweis et al 2008), (Abdul-Rahman et al 2006), } \\
\text { (Kazaz et al 2012) }\end{array}$ \\
\hline 20 & Equipment maintenance & $\begin{array}{l}\text { (Alwi and Hampson, 2003), (Enshassi et al 2009), (Ogunlana } \\
\text { 1996), (Kaming et al 1997), (Elinwa and Joshua 2001), } \\
\text { (Ahmed et al 2002), (Kaming et al 1997), (Elinwa and Joshua } \\
\text { 2001), Odeh et al 2002) (Sweis et al 2008), }\end{array}$ \\
\hline 21 & $\begin{array}{l}\text { Inaccurate prediction of equipment production } \\
\text { rate }\end{array}$ & $\begin{array}{l}\text { (Ogunlana 1996), (Kaming et al 1997), (Sweis et al 2008), } \\
\text { (Ogunlana et al1996), }\end{array}$ \\
\hline 22 & Delay in payment & $\begin{array}{l}\text { (Alwi and Hampson, 2003), (Enshassi et al 2009), (Ogunlana } \\
\text { 1996), (Kaming et al 1997), (Ahmed et al 2002), (Chan and } \\
\text { Kumaraswamy 2002) (Odeh et al 2002) (Al-Najjar 2008), } \\
\text { (Sweis et al 2008), (Mahamid 2017), (Zaneldin 2006) (Kazaz } \\
\text { et al 2012) (Imran Latif 2019), (Alias Imran Latif et al 2020). }\end{array}$ \\
\hline 23 & Contractor's financial problems & $\begin{array}{l}\text { (Odeh et al 2002) (Sweis et al 2008), (Ogunlana et al1996), } \\
\text { (Zaneldin 2006) (Kazaz et al 2012) (Imran Latif 2019), (Alias } \\
\text { Imran Latif et al 2020). }\end{array}$ \\
\hline 24 & Poor Site Management & $\begin{array}{l}\text { (Alwi and Hampson, 2003), (Enshassi et al 2009), (Ogunlana } \\
\text { 1996), (Kaming et al 1997), (Ahmed et al 2002), (Chan and } \\
\text { Kumaraswamy 2002) (Odeh et al 2002) (Al-Najjar 2008), } \\
\text { (Sweis et al 2008), (Mahamid 2017), (Zaneldin 2006) (Kazaz } \\
\text { et al 2012) (Imran Latif 2019), (Alias Imran Latif et al 2020). }\end{array}$ \\
\hline
\end{tabular}




\begin{tabular}{lll}
\hline No Delay Factors & References \\
\hline
\end{tabular}

(Alwi and Hampson, 2003), (Enshassi et al 2009), (Ogunlana 1996), (Kaming et al 1997), (Ahmed et al 2002), (Chan and

25 Defective work/Rework

Kumaraswamy 2002) (Odeh et al 2002) (Al-Najjar 2008), (Sweis et al 2008), (Mahamid 2017), (Zaneldin 2006) (Kazaz et al 2012) (Imran Latif 2019), (Alias Imran Latif et al 2020).

26 Inappropriate construction methods

(Alwi and Hampson, 2003), (Kazaz et al 2012)

(Alwi and Hampson, 2003), (Enshassi et al 2009), (Ogunlana 1996), (Kaming et al 1997), (Ahmed et al 2002), (Chan and

27 Testing and acceptance criteria of Consultant Kumaraswamy 2002) (Odeh et al 2002) (Al-Najjar 2008), (Sweis et al 2008), (Mahamid 2017), (Zaneldin 2006) (Kazaz et al 2012) (Imran Latif 2019), (Alias Imran Latif et al 2020). (Alwi and Hampson, 2003), (Enshassi et al 2009), (Ogunlana 1996), (Kaming et al 1997), (Ahmed et al 2002), (Chan and

28 Design changes by Client or Consultant Kumaraswamy 2002) (Odeh et al 2002) (Al-Najjar 2008), (Sweis et al 2008), (Mahamid 2017), (Zaneldin 2006) (Kazaz et al 2012) (Imran Latif 2019), (Alias Imran Latif et al 2020). (Alwi and Hampson, 2003), (Enshassi et al 2009), (Ogunlana 1996), (Kaming et al 1997), (Ahmed et al 2002), (Chan and

29 Planning and schedule deficiencies Kumaraswamy 2002) (Odeh et al 2002) (Al-Najjar 2008), (Sweis et al 2008), (Mahamid 2017), (Zaneldin 2006) (Kazaz et al 2012) (Imran Latif 2019), (Alias Imran Latif et al 2020). (Alwi and Hampson, 2003), (Enshassi et al 2009), (Ogunlana

30 Deficiencies in coordination between parties(Contractor, Consultant and Owner) 1996), (Kaming et al 1997), (Elinwa and Joshua 2001), Odeh et al 2002) (Sweis et al 2008), (Abdul-Rahman et al 2006),

\begin{tabular}{|c|c|c|}
\hline 31 & Unrealistic contract durations imposed by owner & $\begin{array}{l}\text { (Alwi and Hampson, 2003), (Zaneldin 2006) (Kazaz et al } \\
\text { 2012) }\end{array}$ \\
\hline 32 & Social and cultural factors & $\begin{array}{l}\text { (Alwi and Hampson, 2003), (Orangi et al 2011), (Ogunlana et } \\
\text { al1996), }\end{array}$ \\
\hline 33 & $\begin{array}{l}\text { Slowness of the client's decision-making } \\
\text { process }\end{array}$ & $\begin{array}{l}\text { (Alwi and Hampson, 2003), (Enshassi et al 2009), (Ogunlana } \\
\text { 1996), (Kaming et al 1997), (Elinwa and Joshua 2001), Odeh } \\
\text { et al 2002) (Sweis et al 2008), (Abdul-Rahman et al 2006), }\end{array}$ \\
\hline 34 & Inappropriate type of contract used & $\begin{array}{l}\text { (Alwi and Hampson, 2003), (Enshassi et al 2009), (Chan and } \\
\text { Kumaraswamy 2002) }\end{array}$ \\
\hline 35 & Organizational structure/culture & (Ahmed et al 2002), (Odeh et al 2002) (Al-Najjar 2008), \\
\hline 36 & Customer/ end-user related issues & (Orangi et al 2011), (Abdul-Rahman et al 2006) \\
\hline
\end{tabular}

Table 1 listed 36 factors which can delay the construction projects which appeared in many research articles. These factors were used as the main component of the questionnaire survey conducted for this study which intended to investigate the most common and most significant factors contributing to delay in Saudi Arabia railway/metro construction projects.

\section{Methodology}

This study adopted quantitative approach where the data was collected using structured questionnaire survey. The questionnaire contained list of delay factors together with 5 points Likert scale to capture the level of importance and it frequency of occurrence. For the level of importance, Likert scale 1 means very low and Likert 5 means very high while for the frequency, likert scale 1 means never and likert scale 5 means always. Regarding the sample size, this study used the following formula was used for the sample data collection:

Number of sample, $n=\frac{N \times X}{(X+N-1)}$

Where $\mathrm{N}$ is the population size and $X=\left(Z_{\propto / 2}\right)^{2} \times p \times \frac{(1-p)}{E^{2}}$

$Z_{\alpha / 2}$ is the normal distribution with confidence level of $95 \%$ and

$\mathrm{E}$ is the error margin and lastly, $\mathrm{p}$ is sample proportion.

Based on the formula 1, the calculated sample size for this study is 120 . Hence the study selected 120 respondents who are having more than five (5) years of experience working in railway/metro construction projects. These 
respondents are professionals working on the Riyadh Metro project which spans around 176 KM with 85 stations. The respondents were clustered into client, consultant or contractor across the project. However, only 105 of the respondents responded where the collected data later was compiled for analysis.

The collected data was evaluated through statistical techniques known as Frequency Adjusted Importance Index (FAII). Based on this index, the ranking analysis was conducted. FAII value is the multiplication of Relative Importance Index (RII) and Frequency Index (FI) values. The Frequency Adjusted Importance Index (FAII) was developed to consider the effect of RII and FI together as suggested by the following formula (Ferdin \& Fassa, 2019):

$$
\begin{aligned}
& \text { Frequency Adjusted Importance Index, } F A I I=R I I \times F I \\
& \text { Relative Importance Index, } R I I \%=\left(\frac{\sum W}{A} \times N\right) \times 100 \\
& \text { Frequency Index, } F I \%=\left(\frac{\sum W}{A} \times N\right) \times 100 \\
& \text { Where, W }=\text { weight given to each factor (importance/frequency) by the respondents (1-5), } \\
& \quad \mathrm{A}=\text { the highest weight (in this case is 5), } \\
& \mathrm{N}=\text { total number of respondents. }
\end{aligned}
$$

\section{Respondents' Demography}

The survey form was sent to the respondents that are currently working in railway construction to collect the data. About 120 respondents were selected from railway projects with each group (Client, Consultant or Contractor) were taken into consideration to ensure equal representation in regards to the research results. The entirety of the respondents was from the Riyadh Metro project which is currently in its final construction phase. From the data collection, sample size was 120 but only 105 respondents answered to the questionnaire survey. In the survey, 42 responses were respondents from the client group or representing the client as consultants whilst the remaining 63 responses were from the contractor group.

Table 1 - Responses based on working group

\begin{tabular}{ccc}
\hline Working group & $\begin{array}{c}\text { Response } \\
\text { percent }\end{array}$ & $\begin{array}{c}\text { Response } \\
\text { count }\end{array}$ \\
\hline Client & $15 \%$ & 16 \\
\hline Consultant & $30 \%$ & 32 \\
\hline Contractor & $54 \%$ & 57 \\
\hline
\end{tabular}

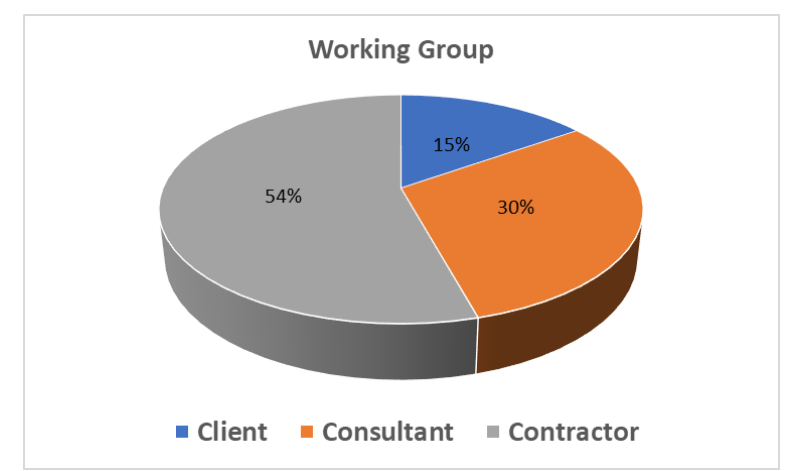

In the questionnaire survey for the experience in the construction industry, the three categories were formed. Table 2 illustrates the respondent's years of working experience for the 3 working groups.

Table 2 - Respondent working experience

\begin{tabular}{ccc}
\hline Years of working experience & $\begin{array}{c}\text { Response } \\
\text { percent }\end{array}$ & $\begin{array}{c}\text { Response } \\
\text { count }\end{array}$ \\
\hline $6-10$ & $31 \%$ & 33 \\
\hline $11-15$ & $38 \%$ & 40 \\
\hline more than 15 & $30 \%$ & 32 \\
\hline
\end{tabular}

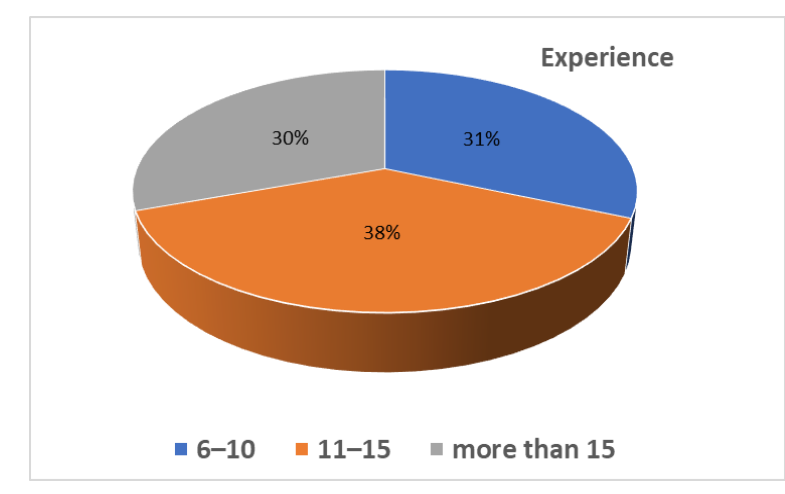


Table 3 - Respondent Qualification

\begin{tabular}{ccc}
\hline Qualification & $\begin{array}{c}\text { Response } \\
\text { percent }\end{array}$ & $\begin{array}{c}\text { Response } \\
\text { count }\end{array}$ \\
\hline Diploma & $4 \%$ & 4 \\
\hline Graduate & $64 \%$ & 67 \\
\hline Master's & $30 \%$ & 32 \\
\hline Ph.D. & $2 \%$ & 2 \\
\hline
\end{tabular}

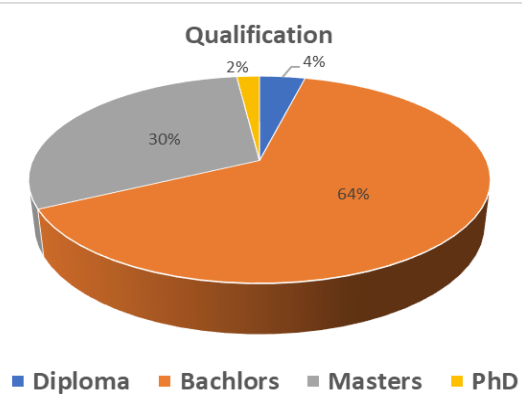

\section{Ranking of the Delay Factors}

The thirty-six (36) delay factors were identified from reviewing the literature which were then designed to be the questionnaire items which the respondents answered. Table 4 below presents the Frequency Adjusted Importance Index by showing the RII, FI and FAII values, along with the ranking of each factor based by the responses made by the respondents.

Table 4 - Frequency Adjusted Importance Index (FAII)

\begin{tabular}{|c|c|c|c|c|}
\hline Delay Factor & $\begin{array}{l}\text { RII } \\
(\%)\end{array}$ & $\begin{array}{c}\text { FI } \\
(\%)\end{array}$ & $\begin{array}{c}\text { (FAII) } \\
\% \\
\end{array}$ & $\begin{array}{l}\text { FAII } \\
\text { Rank }\end{array}$ \\
\hline Inaccurate supplemental design information & 74.48 & 65.71 & 48.941 & 6 \\
\hline Construction site conditions (location, weather, hazard etc.) & 67.43 & 63.24 & 42.641 & 11 \\
\hline Client's decision-making process and changes in control procedures & 78.86 & 71.05 & 56.026 & 1 \\
\hline Insufficient communication between the owner(s) and the $2(\mathrm{~s})$ & 59.05 & 59.81 & 35.316 & 20 \\
\hline Design team experience & 69.71 & 55.81 & 38.907 & 15 \\
\hline Design errors (including ambiguities and discrepancies of details/ specifications) & 75.81 & 72.57 & 55.016 & 2 \\
\hline Issues regarding permissions/ approvals from other stakeholders & 71.43 & 72.38 & 51.701 & 5 \\
\hline External work due to public agencies, Government regulation & 69.14 & 42.67 & 29.501 & 28 \\
\hline Delivery of material & 73.52 & 50.29 & 36.972 & 17 \\
\hline Poor procurement programming of materials & 67.43 & 50.10 & 33.779 & 21 \\
\hline Storage of material & 58.29 & 42.48 & 24.758 & 30 \\
\hline Low quality of materials & 68.95 & 47.43 & 32.703 & 24 \\
\hline Material supply monopoly & 62.10 & 50.10 & 31.107 & 26 \\
\hline Lack of trades skill & 65.14 & 50.10 & 32.633 & 25 \\
\hline Labor skills level & 74.29 & 72.38 & 53.769 & 3 \\
\hline Availability of labor & 71.43 & 49.90 & 35.646 & 19 \\
\hline Productivity of labor & 75.05 & 57.52 & 43.170 & 10 \\
\hline Equipment quality & 60.57 & 35.05 & 21.229 & 34 \\
\hline Equipment breakdown & 61.33 & 35.05 & 21.496 & 33 \\
\hline Equipment maintenance & 60.00 & 35.05 & 21.029 & 35 \\
\hline Inaccurate prediction of equipment production rate & 62.86 & 35.05 & 22.030 & 32 \\
\hline Delay in payment & 67.24 & 62.29 & 41.880 & 13 \\
\hline Contractor financial problems & 68.19 & 57.33 & 39.096 & 14 \\
\hline Poor Site Management & 71.43 & 64.95 & 46.395 & 8 \\
\hline Defective work/Rework & 74.48 & 64.76 & 48.232 & 7 \\
\hline Inappropriate construction methods & 67.43 & 44.95 & 30.311 & 27 \\
\hline Testing and acceptance criteria of 2 & 60.57 & 55.05 & 33.343 & 22 \\
\hline Design changes by Client or Consultant & 80.38 & 64.76 & 52.056 & 4 \\
\hline Planning and schedule deficiencies & 70.48 & 59.81 & 42.151 & 12 \\
\hline Deficiencies in coordination between parties & 65.90 & 55.05 & 36.279 & 18 \\
\hline Unrealistic contract durations imposed by owner & 70.67 & 37.52 & 26.517 & 29 \\
\hline Social and cultural factors & 49.14 & 47.43 & 23.308 & 31 \\
\hline Slowness of the Client's decision-making process & 67.43 & 64.76 & 43.668 & 9 \\
\hline Inappropriate type of contract used & 65.90 & 49.90 & 32.890 & 23 \\
\hline Organizational structure/culture & 62.10 & 62.48 & 38.795 & 16 \\
\hline Customer/ end-user related issues & 56.38 & 35.05 & 19.760 & 36 \\
\hline
\end{tabular}


Table 4 shows the ranking of the factors that are mostly responsible for causing delays based on the results of the Frequency Adjusted Importance Index (FAII). The factor of "client's decision-making process and changes in control procedures" is the most critical delay causing factor. It was often due to the client's ill-advised judgement and lacks experience or know-how in the field which consequently adds delays to the project. The $2^{\text {nd }}$ and $4^{\text {th }}$ factors were both related to design issues (errors, delays, inaccurate supplemental design information, and changes to the design) which are essential factors that contribute in delaying the construction of the project. Additionally, the design errors indicate incorrect or unsatisfactory project deliverables which results in wrong utilization or incorrect procedures when it came to the execution phase. This highlights the importance of employing an experienced design team to generate a detailed error-free design to avoid delays. The changes prompted by the client can also be avoided by better design at the early stages. The "labor skills level" factor is ranked $3^{\text {rd }}$ in the analysis of the most critical delaying factor. It generally recognized that project execution depends on the aptitudes of the workers during the construction, whose abilities and capacities can influence the project performance to a better or to a lesser degree. The delay factor issues regarding permissions/approvals from other stakeholders is ranked $5^{\text {th }}$ in the analysis. As the Riyadh Metro project is in the urban area of the city, many stakeholders are currently involved in the approvals and permit for the proceeding of the Riyadh Metro related activities. The coordination of each entity is vital as to avoid future delay.

\section{Conclusion}

This paper recognized and assessed the primary delay factors in the construction of the Riyadh Metro project, Saudi Arabia. Initially, thirty-six factors were distinguished by literature review and afterwards, these variables were assessed by respondent's answer to the questionnaire regarding the importance and frequency of each factor. Frequency Adjusted Importance Index was (FAII) was utilized to gauge and evaluate the significance of the delay factors. By ranking the delay factors based on its values of importance and frequency, the result of this research identified the top five main delay factors to the railway construction projects which are "Client's decision-making process and changes in control procedures", "Design Errors (including ambiguities and discrepancies of details/specifications)", "Labor skills level", "Design changes by Client or Consultant" and lastly, "Issues regarding permissions/ approvals from other stakeholders". This study would benefit the professionals in railway construction industry and scholars with this finding as it will help them to distinguish the level of this examination by giving the most thought to the delay factors distinguished by this investigation. Finally, this study is hoped to help the railway construction industry in bettering itself by highlighting which issues should be focused on to counter the delays and reduce downtimes.

\section{References}

Gunduz M, Nielsen Y, Ozdemir M (2015) "Fuzzy assessment model to estimate the probability of delay in Turkish construction projects,” J. Manag. Eng., vol. 31, no. 4

Hossen M. M., Kang S, Kim J, (2015) “Construction schedule delay risk assessment by using combined AHP-RII methodology for an international NPP project,” Nucl. Eng. Technol., vol. 47, no. 3, pp. 362-379

Gardezi S. S. S, Manarvi I. A, Gardezi S. J. S, (2014) "Time extension factors in construction industry of Pakistan," Procedia Eng., vol. 77, pp. 196-204

Van L. T, Sang N. M, Viet N. T, (2016)“A conceptual model of delay factors affecting government construction projects,” ARPN J. Sci. Technol., vol. 5, no. 2, pp. 92-100

Marzouk M. M and El-Rasas T. I, (2014) “Analyzing delay causes in egyptian construction projects,” J. Adv. Res., vol. 5, no. 1, pp. 49-55

Aziz R. F, (2013) "Ranking of delay factors in construction projects after Egyptian revolution,” Alexandria Eng. J., vol. 52, no. 3, pp. 387-406

Apolot R., Alinaitwe H, Tindiwensi D., (2011) "An Investigation into the Causes of Delay and Cost Overrun in Uganda's Public Sector Construction Projects,” J. Constr. Dev. Ctries., vol. 18, no. 2, pp. 33-47

Assaf S. A. and Al-Hejji S, (2006) “Causes of delay in large construction projects,” Int. J. Proj. Manag., vol. 24, no. 4, pp. 349-357

Al-Kharashi A. and Skitmore M., (2009) "Causes of delays in Saudi Arabian public sector construction projects," Constr. Manag. Econ., vol. 27, no. 1, pp. 3-23 
Al-ghafly M. A., (1999) "Delay in the Construction of Public Utility Projects in Saudi Arabia," Int. J. Proj. Manag., vol. 17 , no. 2 , pp. 101-106

Faridi A. S. and El-Sayegh S. M., (2006) "Significant factors causing delay in the UAE construction industry," Constr. Manag. Econ., vol. 24, no. 11, pp. 1167-1176

Turkey A, (2011) "The reality of projects in terms of organization and structure, and the reasons for success and failure In Saudi Arabia," Alwatan Newsp.,

Alsuliman J, Bowles G, and Chen Z, (2012) "Current practice of variation order management in the Saudi construction industry,” Assoc. Res. Constr. Manag. ARCOM 2012 - Proc. 28th Annu. Conf., vol. 2, pp. 1003-1012

Senouci A., Ismail A. A., and Eldin N., (2016) "Time and Cost Overrun in Public Construction Projects in Qatar," Creat. Constr. Conf. 2016, pp. 231-236

Alwi S. and Hampson K., (2003) "Identifying the Important Causes of Delays in Building Construction Projects," 9th East Asia-Pacific Conf. Struct. Eng. Constr., pp. 319-335

Enshassi A., Al Najjar J., and Kumaraswamy M., (2009) "Delays and cost overruns in the construction projects in the Gaza Strip,” J. Financ. Manag. Prop. Constr., vol. 14, no. 2, pp. 126-151

Ogunlana S. O., Promkuntong K., and Jearkjirm V., (1996) "Construction delays in a fast-growing economy: Comparing Thailand with other economies,” Int. J. Proj. Manag., vol. 14, no. 1, pp. 37-45

Kaming P. F, Olomolaiye P. O, Holt G. D, and Harris F. C, (1997) "Factors influencing construction time and cost overruns on high-rise projects in Indonesia,” Constr. Manag. Econ., vol. 15, no. 1, pp. 83-94

Elinwa A. U. and Joshua M., (2001)“Time-overrun factors in Nigerian construction industry,” J. Constr. Eng. Manag., vol. 127 , no. 5 , pp. $419-425$

Ahmed S. M., Azhar S., Castillo M., andKappagantula P., (2002) "Construction Delays in Florida: An Empirical Study," ASC Proc. 39th Annu. Conf., pp. 491-500

Chan D. W. M. and Kumaraswamy M. M., (2002) "Compressing construction durations: Lessons learned from Hong Kong building projects,” Int. J. Proj. Manag., vol. 20, no. 1, pp. 23-35

Odeh A. M. and Battaineh H. T., (2002) “Causes of construction delay: Traditional contracts,” Int. J. Proj. Manag., vol. 20, no. 1 , pp. 67-73

Al-Najjar J. M., ( 2008) “Factors Influencing Time and Cost Overruns on Construction Projects in the Gaza Strip,” Int. J. Phys. Soc. Sci., pp. 1-219

Orangi A., Palaneeswaran E., and Wilson J., (2011) "Exploring delays in Victoria-based Astralian pipeline projects," Procedia Eng., vol. 14, pp. 874-881

Sweis G., Sweis R., Abu Hammad A., and Shboul A., (2008) “Delays in construction projects: The case of Jordan,” Int. J. Proj. Manag., vol. 26, no. 6, pp. 665-674

Mahamid I., (2017)“Schedule Delay in Saudi Arabia Road Construction Projects: Size, Estimate, Determinants and Effects,” Int. J. Archit. Eng. Constr., vol. 6, no. 3

Chan Z. C. Y., Fung Y. L., and Chien W. T., (2013) "Bracketing in phenomenology: Only undertaken in the data collection and analysis process?," Qual. Rep., vol. 18, no. 30

Zaneldin E. K., (2006) "Construction claims in United Arab Emirates: Types, causes, and frequency,” Int. J. Proj. Manag., vol. 24, no. 5, pp. 453-459

Le-Hoai L., Lee Y. D., and Lee J. Y., (2008) "Delay and cost overruns in Vietnam large construction projects: A comparison with other selected countries,” KSCE J. Civ. Eng., vol. 12, no. 6, pp. 367-377 
Abdul-Rahman H., Berawi M. A., Berawi A. R., Mohamed O., Othman M., and Yahya I. A., (2006) "Delay mitigation in the Malaysian construction industry," J. Constr. Eng. Manag., vol. 132, no. 2, pp. 125-133

Kazaz A., Ulubeyli S., and Tuncbilekli N. A., (2012) "Causes of delays in construction projects in Turkey," J. Civ. Eng. Manag., vol. 18, no. 3, pp. 426-435

Alghbari, (2013) “The significant factors causing delay of building construction projects in Malaysia Good.pdf," no. March, 2013

Gunduz M. and Yahya A. M. A., (2018) “Analysis of project success factors in construction industry,” Technol. Econ. Dev. Econ., vol. 24, no. 1, pp. 67-80

Alias Imran Latif , Q. B. (2020). Oman Construction Industry Prospective on Cause of Construction Material Waste. International Journal of Integrated Engineering, 12(1), 243-252

Imran Latif, Q. B. alias, Al Saadi, A. M. D., \& Abdul Rahman, I. (2019). Identification of Delay Factor in Oman Construction Industry. International Journal of Sustainable Construction Engineering and Technology, 10(1), Pp 34-45 